\title{
UNA OBRA INÉDITA DEL ESCULTOR JUAN DE ASTORGA EN LA IGLESIA PARROQUIAL DE UMBRETE
}

\author{
AN UNKNOWN WORK OF SCULPTOR JUAN DE \\ ASTORGA IN THE PARISH CHURCH OF UMBRETE
}

\author{
Francisco Amores Martínez \\ famoresm@yahoo.es
}

\begin{abstract}
En el presente trabajo nos proponemos realizar una nueva aportación al catálogo escultórico de Juan de Astorga, una obra existente en la iglesia parroquial de Umbrete, realizada por encargo de Francisco Javier Cienfuegos, cardenal arzobispo de Sevilla.

Palabras clave: Astorga, escultura, siglo XIX, Umbrete (Sevilla), cardenal Cienfuegos.

In this article we propose to make a new contribution to the sculpture catalog of Juan de Astorga, a work existing in the parish church of Umbrete, commissioned by Francisco Javier Cienfuegos, Archbishop of Seville.

Keywords: Astorga, sculpture, nineteenth century, Umbrete (Sevilla), Cardinal Cienfuegos.
\end{abstract}

Desde que en 1313 el arzobispo de Sevilla obtuviese licencia para poblar la antigua alquería musulmana de Umbrete, que había sido donada por Alfonso X a la Iglesia hispalense en 1260, su templo parroquial fue considerado capilla propia de los prelados, que fueron sus patronos hasta la desaparición de los señoríos jurisdiccionales en el siglo XIX. Es por ello que muchos de ellos dejaron su huella en el templo en forma de obras de arte, de lo cual tenemos constancia documental desde el siglo XVII ${ }^{1}$. Junto a la iglesia disponían de una gran casa palacio que se comunicaba directamente con ella mediante un arco y un pasillo superior,

${ }^{1}$ AMORES MARTÍNEZ, Francisco: "El mecenazgo artístico de los arzobispos sevillanos en su villa de Umbrete durante los siglos XVII y XVIII", en Nuevas perspectivas sobre el barroco andaluz. Arte, Tradición, Ornato y Símbolo. Córdoba, 2015, pp. 271-288. 
lugar de recreo y descanso en la que muchos de los arzobispos pasarían temporadas más o menos largas, costumbre que se incrementaría a raíz de su ampliación por Luis de Salcedo y Azcona a comienzos del siglo XVIII. Pues bien, una de esas obras de arte que aún permanecen en el templo es una escultura que representa al Ángel de la Guarda, que se expone actualmente en el interior de una vitrina en el salón que se halla sobre la sacristía, habilitado hace algunos años como museo parroquial. En las líneas que siguen nos proponemos dar noticia de las circunstancias de su llegada a Umbrete, así como de su autoría, que hemos podido documentar recientemente.

La iglesia de Nuestra Señora de Consolación había sido construida a expensas del mencionado arzobispo Salcedo y Azcona entre los años 1725 y 1733, y adornada en los años siguientes con suntuosos retablos y pinturas que se dispusieron en el presbiterio, el crucero y las cinco capillas laterales (en la restante de las seis existentes se hallaba la puerta lateral de acceso al templo). Al comenzar el siglo XIX, puede decirse que en una de ellas, la primera del lado del evangelio, la decoración se hallaba aun incompleta, estando ocupado solamente su testero principal con un lienzo de Santa Bárbara, magnífica pintura debida a Domingo Martínez. En una de sus visitas a la villa, en la primavera del año 1827, el entonces arzobispo de Sevilla Francisco Javier Cienfuegos y Jovellanos tuvo a bien disponer que en esta capilla se colocasen en los laterales sendos altares, destinándose uno de ellos a la imagen de San Sebastián que poseía la parroquia, interesante talla anónima del siglo XVI, mientras que el otro se dedicaría a acoger una nueva imagen que se habría de adquirir en la capital hispalense, la cual por indicación del propio cardenal no fue otra que una escultura que representaba al Santo Ángel de la Guarda o Ángel Custodio. Esta obra sería encargada al escultor Juan de Astorga Cubero (Archidona, 1777-Sevilla, 1849), según consta en el asiento correspondiente del libro de cuentas de fábrica de la parroquia, registrado por el cura Miguel Pacheco y Cabrera, encargado entonces de administrar los bienes de la Dignidad Arzobispal en la villa de Umbrete. Según dicho asiento, consta haber pagado en el mes de julio de dicho año 1827 trescientos reales " $a$ D. Juan de Astorga por el Ángel Custodio, según recibo" 2 . El día 23 de agosto se trajo la imagen desde Sevilla, y ese mismo mes se colocó en el nuevo y modesto altar de la mencionada capilla de Santa Bárbara, cuya realización supuso un coste en obras de albañilería de ciento noventa y tres reales. Todo ello se hizo, según indica el cura, "por disposición del Emmo. Sr. Arzobispo, mi Señor". Finalmente, en junio del año siguiente el carpintero local Isidoro Guerra realizaría una peana de madera para la talla, con el fin de que alcanzase mayor altura. A finales de aquel siglo XIX la misma sería retirada de la capilla de Santa Bárbara y colocada en otro lugar del templo, concretamente sobre la mesa del altar dedicado a San José en la tercera

2 APU (Archivo Parroquial de Umbrete). Libro de cuentas de fábrica (1825-1829), $\sin$ foliar. 
capilla del lado de la epístola, según se afirma en el inventario realizado el año $1913^{3}$, y en ese lugar permanecería hasta los años centrales del siglo XX, cuando sería retirada definitivamente del templo para ser depositada alternativamente en la sacristía y en la casa parroquial, habiendo sufrido a causa de tantos traslados un notable deterioro.

La realización de esta escultura hay que ponerla en relación con la presencia del cardenal Cienfuegos en Umbrete durante la primera parte de su pontificado, desde su elección como prelado de la diócesis en 1824 hasta que se ausentó de ella tras ser desterrado a Alicante en febrero de $1836^{4}$. Hemos podido documentar su presencia en la villa en tres ocasiones, el cuatro de octubre de 1825, el veinte de enero de 1826 y el ocho de mayo de 1827, fechas en que administró el sacramento de la Confirmación a otros tantos grupos de fieles ${ }^{5}$. Asimismo nos consta que se encontraba en el pueblo en el mes de octubre de este último año, siendo entonces cuando mandó cerrar la callejuela contigua a la iglesia en su fachada meridional, debido a los desórdenes públicos que en este angosto lugar se producían, costando la obra, dirigida por el maestro Santiago García de Lallosa, 52 reales $^{6}$. Esta calle ha sido de nuevo abierta a comienzos del presente siglo, recuperando así la visión completa que tuvo el templo en sus orígenes. En esas mismas fechas, por disposición del arzobispo, se efectuaron también importantes obras de reforma del cementerio parroquial, que concluyeron al año siguiente. Por otra parte, de gran relevancia sería el decreto que el cardenal firmó el día catorce de noviembre de 1832, mediante el cual hacía donación a la fábrica parroquial de todos los tributos que hasta entonces pagaban los vecinos a la Dignidad Arzobispal. En este documento don Francisco Javier se titulaba "Señor de esta mi Villa de Umbrete, único Patrono de su Iglesia Parroquial, su Dotador y perpetuo sostenedor", y añadía que hacía este gesto "por el mucho amor y afecto que le profeso", y "bien instruido de mi derecho y sin otro motivo ni respecto más que la escasez de medios en que se halla la fábrica de esta su citada Iglesia"7. Al cardenal le correspondería años después la penosa tarea de dar por concluida la larga etapa de más de cinco siglos en la que Umbrete había pertenecido a la Mitra sevillana, y desde

${ }^{3}$ APU. Inventario de la Iglesia Parroquial de Ntra. Sra. de Consolación, única de esta villa de Umbrete, con las alhajas, ornamentos y demás enseres pertenecientes a esta parroquia, hecho el año 1913. Realizado por el párroco Juan Jiménez Román.

${ }^{4}$ ROS, Carlos: Los Arzobispos de Sevilla. Luces y sombras en la sede hispalense. Sevilla, 1986, p. 245.

5 APU. Libro XII de bautismos, sin foliar.

${ }^{6}$ APU. Libro de cuentas de fábrica (1825-1829). "Octubre de 1827. Día 15. Se empezó a cerrar la Callejuela contigua a la Iglesia, obra determinada por S. Em ${ }^{a}$ el Cardenal Arzobispo mi Señor".

7 AMORES MARTÍNEZ, Francisco: "Un señorío eclesiástico en la Andalucía del Antiguo Régimen. Los arzobispos sevillanos, señores del Valle de Umbrete", en Actas del III Congreso de Historia de Andalucía. Córdoba, 2001, t. IV, p. 31. 
su destierro hubo de ser informado de la incautación del palacio arzobispal de la misma en 1841, con el consiguiente desmantelamiento de sus espléndidos jardines, si bien hubo tiempo de salvar las pinturas que allí había, depositándolas en la iglesia parroquial.

En cuanto a los motivos que llevaron a elegir esta advocación para la nueva imagen de Umbrete, hay que señalar que el cardenal Cienfuegos fue un activo propagandista de la devoción al Santo Ángel Custodio, cuyo culto fue promovido por el rey Fernando VII a finales del año 1823, cuando recuperó el poder en España, según algunos autores "para darle gracias por la asistencia con que nos favorece, por haber puesto fin al cautiverio del Rey y a tantas calamidades como acaba de pasar España y para impetrar su auxilio y protección en los tiempos venideros", y a instancias del monarca dispuso el papa León XII, que había accedido al solio pontificio aquél mismo año, que se fijara la festividad del Santo Ángel el día primero de octubre con rito doble de segunda clase con octava. No cabe duda de que la sintonía ideológica del arzobispo hispalense con el rey absolutista influyó de manera importante para que en nuestra diócesis se difundiese esta devoción durante aquellos años. En este sentido, se conserva una estampa decimonónica que contiene una oración que con toda probabilidad fue compuesta por el mismo prelado o alguien de su círculo, pues al final de la misma figura la siguiente leyenda: "El Emmo. y Excmo. Sr. D. Francisco Xavier Cienfuegos, Cardenal Arzobispo de esta Diócesis, concede 100 días de Indulgencia a todos los que digan esta oración". La plegaria lleva por título "“Oración al Santo Ángel Custodio del Reino", y entre otras cosas dice lo siguiente: "Dios te salve Ángel de Dios, Príncipe gloriosísimo de la Celeste Corte y Protector nuestro piadosísimo: Dios te Salve. A ti te escogió nuestro padre que está en los Cielos por guarda y defensa de estos Reinos encargándoos que los protejáis contra las calamidades que sin cesar nos afligen en justo castigo de nuestros pecados... Como fiel ministro del Señor veláis sobre nosotros de continuo. ¿A quién pues recurriremos en nuestras aflicciones sino a Vos ó Ángel gloriosísimo?". Creemos que el autor debe referirse a sí mismo cuando habla del "fiel ministro del Señor". Otro ejemplo de la predilección de Cienfuegos por esta advocación lo encontramos en la iglesia sevillana de San Alberto, en cuyo altar dedicado a San Felipe Neri figura en el ático una pintura en lienzo del Ángel de la Guarda, copia de Murillo, que el cardenal había regalado a la Congregación del Oratorio, con la que se hallaba muy vinculado desde que, cuando apenas contaba doce años de edad, su tío el también arzobispo Alonso de Llanes le había puesto como preceptor al padre Teodomiro Díaz de la Vega, miembro del citado

${ }^{8}$ FIJO GARAY, Leopoldo: Novena al Santo Ángel Custodio de España. Meditación del día Cuarto. Madrid, 1917.

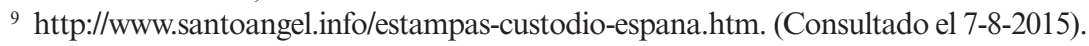


instituto de los filipenses ${ }^{10}$. Finalmente, cuando en agosto de 1825 el arzobispo Cienfuegos tuvo a bien ceder el retablo que había sido de su oratorio privado en el palacio arzobispal a los frailes del convento de San Buenaventura, éstos dedicaron el nuevo altar al Santo Ángel de la Guarda, probablemente por sugerencia del propio donante ${ }^{11}$.

El ángel de Umbrete es una escultura de tamaño académico (mide $64 \mathrm{~cm}$ ), realizada en madera policromada en cabeza, manos y pies, mientras que las vestiduras son de telas encoladas. Actualmente presenta un estado de conservación muy deficiente, pues con el paso del tiempo y los constantes cambios de ubicación ha sufrido importantes daños como grietas en el cuello y el brazo derecho o la pérdida de buena parte de los dedos de las manos, pero sobre todo ha perdido elementos determinantes de su iconografía, como las alas (aunque conserva sus engarces metálicos en la espalda), habiendo desaparecido también la figura infantil que debió ocupar el espacio sobrante de la peana, a la izquierda del ángel, quien parece dirigir a ella su mirada y cogerla de la mano. Se trataría por tanto de una representación de la clásica iconografía del Ángel de la Guarda, que protege al alma cristiana representada en el niño, guiándola en el camino de la vida, y a la que muestra con su mano izquierda el cielo, destino final del viaje, un asunto tomado del pasaje del Libro del Éxodo en el que se dice: "Mira, yo enviaré mi ángel delante de ti para que te cuide en el camino y te lleve al lugar que te he preparado" (Ex 23, 20-22). Así lo había plasmado Murillo en su célebre lienzo pintado para los capuchinos y conservado hoy en la catedral de Sevilla, mientras que en el terreno escultórico contamos con la magnífica imagen que Blas Molner había realizado a finales del siglo XVIII para la iglesia sevillana del Santo Ángel, de los padres carmelitas descalzos ${ }^{12}$, una obra neoclásica de mayor tamaño y dinamismo, pero que pensamos que constituye la referencia más cercana a la imagen que nos ocupa. En ésta, Juan de Astorga, utilizando una combinación de materiales como la madera y la tela encolada que raramente encontramos en su producción ${ }^{13}$, ha conseguido una representación plena de clasicismo y a la vez dotada de un halo romántico que remite a

${ }^{10}$ FERNÁNDEZ, Cayetano: El oratorio de San Felipe Neri de Sevilla: su historia, instituciones, particularidades y biblioteca oratoriana. Sevilla, 1894, p. 463.

11 ACS (Archivo de la Catedral de Sevilla). Fondo Histórico General. Legajo 11.580, $\sin$ foliar.

${ }^{12}$ GONZÁLEZ DE LÉON, Félix: Noticia artística, histórica y curiosa de todos los edificios públicos, sagrados y profanos de esta Muy Noble, Muy Leal, Muy Heroica e Invicta Ciudad de Sevilla, y de muchas casas particulares. Sevilla 1844, pág. 167.

${ }^{13}$ Otro caso similar es el de la imagen del Inmaculado Corazón de María, aunque en este caso de barro en vez de madera, realizada para la parroquia sevillana de San Pedro en 1825. ROS GONZÁLEZ, Francisco S: "Algunas noticias sobre el tallista José Mayorga y el escultor Juan de Astorga”, Laboratorio de arte, 20 (2007), p. 300. 
su etapa de madurez, en la que, superando las rigideces académicas, imprimió a sus imágenes un estilo personal e inconfundible. Siguiendo lo establecido en anteriores representaciones, el ángel aparece descalzo, adelantando la pierna derecha en ademán itinerante, y viste túnica de color amarillo, con otra sobrepuesta a ella de color rosáceo, así como una ancha cinta de color azul anudada en la cintura que desde la espalda cae por encima del hombro izquierdo. Pero es en la talla de la cabeza donde el escultor se ha esmerado, cubierta con cabellera gubiada a base de finas guedejas y cortos mechones. En el rostro ovalado se aprecian rasgos comunes a las imágenes de Astorga como el fino dibujo de las cejas, la nariz recta o el hoyuelo de la barbilla, mientras que los ojos de cristal y la boca cerrada contribuyen a dotarla de una expresión ensimismada y melancólica. Añadamos a todo ello la elegante talla del cuello y la policromía nacarada y rosácea del rostro, como la de manos y pies, y convendremos en encontrarnos ante una obra ciertamente lograda, que supone una versión nada estandarizada del tema que se trata, y cuya conveniente restauración ayudaría a rescatar sus muchos valores plásticos.

Finalmente, recordaremos que la relación de Juan de Astorga con el arzobispo Cienfuegos se remontaba al menos hasta el treinta de julio del año 1825, día en que fue designado por el prelado "maestro ensamblador" del arzobispado", relevante noticia que también era desconocida hasta ahora, según creemos. Un empleo que sin embargo duraría poco tiempo, ya que en el mismo registro del correspondiente libro, figura escrita al margen la siguiente anotación: "se suprimió por S. E. esta Plaza", y efectivamente no consta ningún otro nombramiento posterior para la tarea de diseño y ejecución de retablos en la diócesis, por lo que puede entenderse que Astorga fue el último maestro mayor tallista de la misma, y en este sentido no se ha documentado hasta el momento ningún retablo de su mano encargado por los prelados hispalenses. Por otra parte, dos años más tarde, coincidiendo con la fecha de la hechura de la imagen del ángel para Umbrete, nuestro artista recibiría el encargo por parte del arzobispo de llevar a cabo la parte escultórica de lo que se proyectaba que fuese la portada principal de la fachada occidental de la catedral, para lo cual Astorga realizaría un boceto en barro representando el tema de la Asunción de la Virgen, destinado a ocupar el tímpano de la mencionada portada, obra que finalmente no llegaría a realizarse en aquellos años, conservándose actualmente el boceto en la sacristía mayor de la seo hispalense ${ }^{15}$. No es extraño que desde la máxima instancia eclesiástica de la ciudad se recurriese a Juan de Astorga para estos y otros trabajos, pues como

${ }_{14}$ AGAS (Archivo General del Arzobispado de Sevilla). Medios de información. Legajo 16.432. Libro registro de títulos y despachos de la secretaría del cardenal Cienfuegos

${ }^{15}$ RUIZ ALCAÑIZ, José Ignacio: El escultor Juan de Astorga. Sevilla, 1986, pp. 34-36. 
afirma el profesor Roda Peña, se trataba del escultor "más capacitado y prestigioso de cuantos trabajaron en Sevilla durante la primera mitad del siglo XIX"16.

Fecha de recepción: 10 de agosto de 2015.

Fecha de aceptación: 20 de noviembre de 2015.

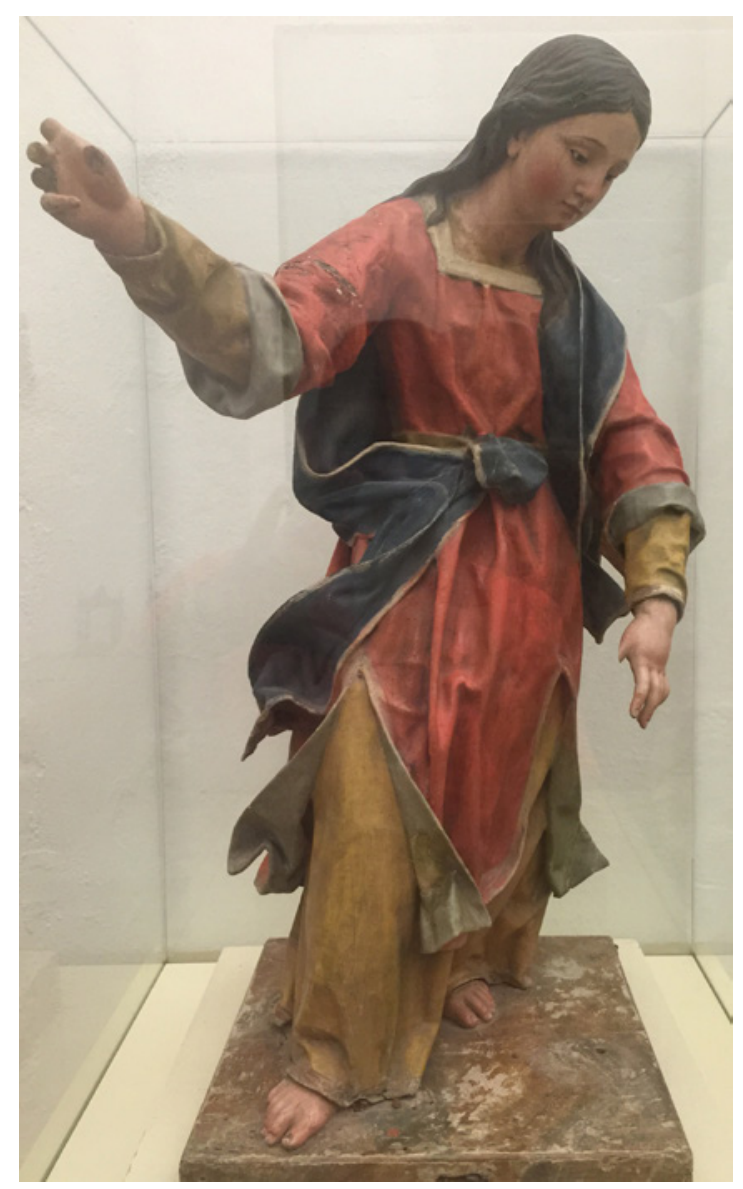

Figura 1. Ángel Custodio. Juan de Astorga, 1827. Foto del autor.

${ }^{16}$ RODA PEÑA, José: "Juan de Astorga: novedades biográficas y aportaciones a su catálogo escultórico", en Nuevas perspectivas críticas sobre historia de la escultura sevillana. Sevilla, 2007, p. 143. 
Francisco Amores Martínez

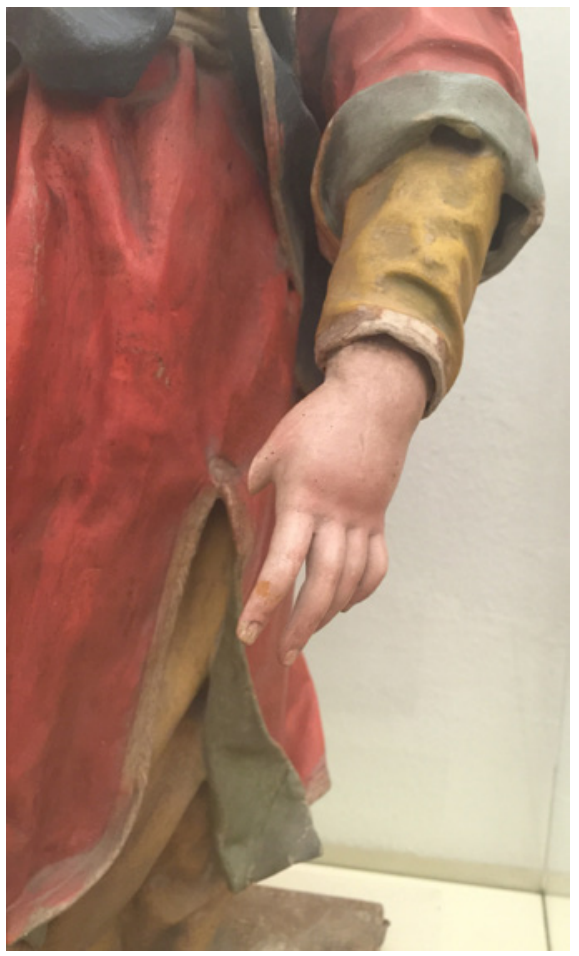

Figura 2. Ángel Custodio. Detalle.

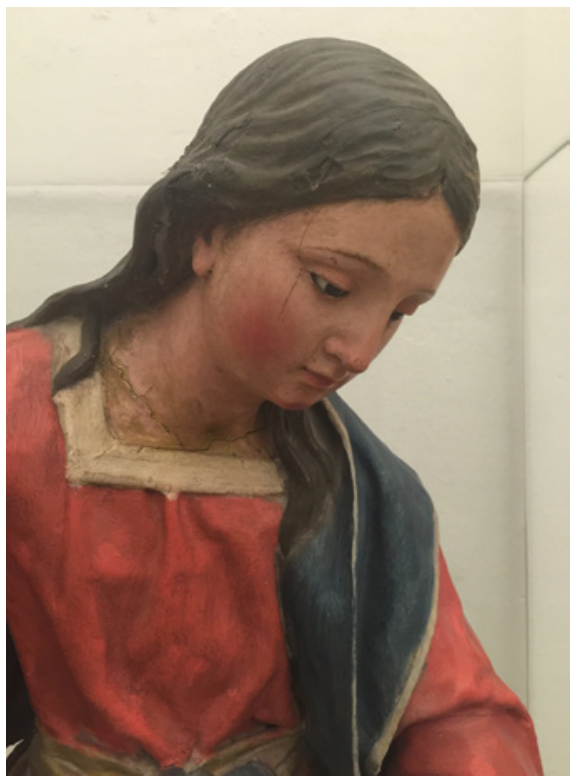

Figura 3. Ángel Custodio. Detalle.

LABORATORIO DE ARTE 28 (2016), pp. 363-371, ISSN 1130-5762

e-ISSN 2253-8305 - DOI http://dx.doi.org/10.12795/LA.2006.i.01.19 


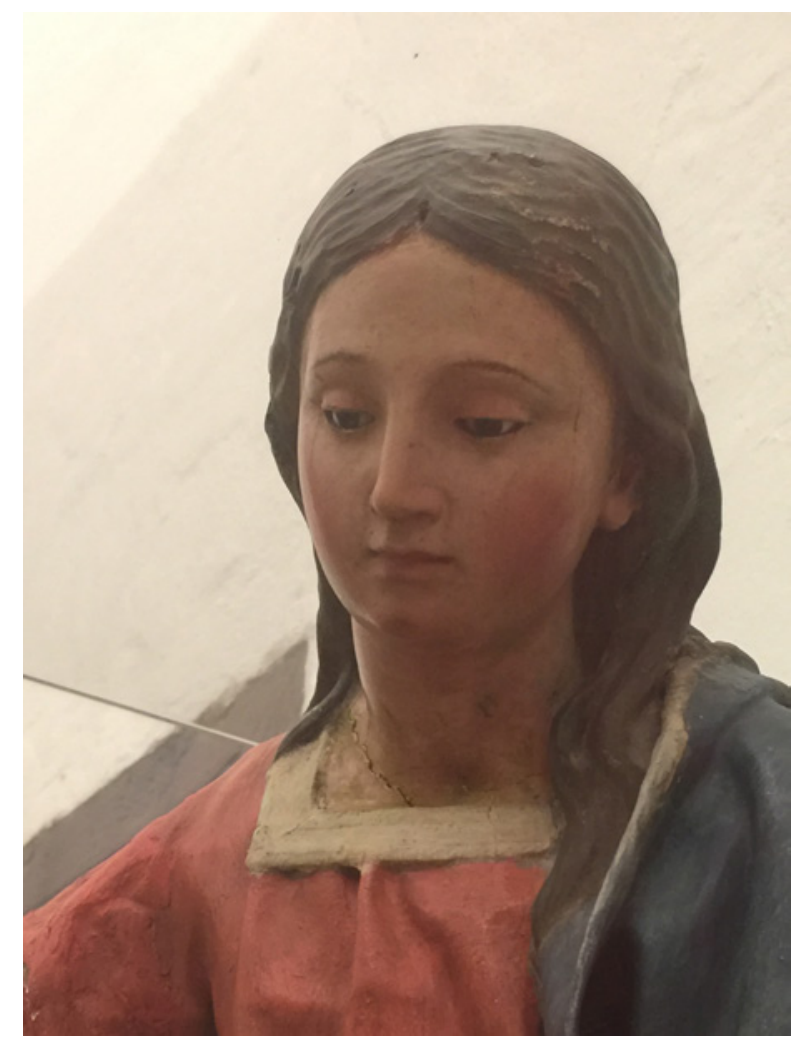

Figura 4. Ángel Custodio. Detalle. 